\title{
Trends of Chlorinated Organic Contaminants in Great Lakes Trout and Walleye from 1970 to 1998
}

\author{
J. P. Hickey, ${ }^{1}$ S. A. Batterman, ${ }^{2}$ S. M. Chernyak ${ }^{2}$ \\ ${ }^{1}$ United States Geological Survey, Great Lakes Science Center, 1451 Green Road, Ann Arbor, Michigan 48105, USA \\ ${ }^{2}$ School of Public Health, University of Michigan, Ann Arbor, Michigan 48109, USA
}

Received: 5 January 2005/Accepted: 19 June 2005

\begin{abstract}
Levels of chlorinated organic contaminants in predator fish have been monitored annually in each of the Great Lakes since the 1970s. This article updates earlier reports with data from 1991 to 1998 for lake trout (Salvelinus namaycush) and (Lake Erie only) walleye (Sander vitreus) to provide a record that now extends nearly 30 years. Whole fish were analyzed for a number of industrial contaminants and pesticides, including polychlorinated biphenyls (PCBs), dichloro-diphenyl-trichloroethane (DDT), dieldrin, toxaphene, and mirex, and contaminant trends were quantified using multicompartment models. As in the past, fish from Lakes Michigan, Ontario, and Huron have the highest levels of PCBs, DDT, and dieldrin; Superior has the highest levels of toxaphene; and Ontario has the highest levels of mirex. In the period after curtailment of chemical use, concentrations rapidly decreased, represented by relatively short half-lives from approximately 1 to 9 years. Although trends depend on both the contaminant and the lake, in many cases the rate of decline has been decreasing, and concentrations are gradually approaching an irreducible concentration. For dioxin-like PCBs, levels have not been decreasing during the most recent 5-year period (1994 to 1998). In some cases, the year-to-year variation in contaminant levels is large, mainly because of food-web dynamics. Although this variation sometimes obscures long-term trends, the general pattern of a rapid decrease followed by slowing or leveling-off of the downward trend seems consistent across the Great Lakes, and future improvements of the magnitude seen in the 1970s and early 1980s likely will take much longer.
\end{abstract}

It is well now recognized that levels of many contaminants in the Great Lakes basin pose significant concerns to human and ecosystem health. Fish consumption advisories because of contaminant residues in fish that exceed guidelines for human consumption, and the disposal of contaminated sediments from

Correspondence to: S. A. Batterman; email: Stuartb@umich.edu channel dredging and site-cleanup activities, are two examples of the continuing challenges posed by the presence of contaminants in the basin. Information regarding the levels and trends of contaminants in the Great Lakes basin is needed to control the use and disposal of contaminants, to set waterquality standards and fish consumption advisories, and to understand the transport and fate of pollutants, including the development of ecosystem models.

This article provides updated information regarding the trends of chlorinated organic contaminants in predator fish in all five Great Lakes through 1998. It builds on earlier studies (De Vault et al. 1985; 1986; 1996) that provided monitoring results for 1970 through 1992. With few exceptions, sampling and analysis protocols during this nearly 30 year-long period remained consistent; thus, this time series record provides an unparalleled and unique opportunity to understand the dynamics of persistent contaminants, especially after the manufacture or use of the chemicals has been curtailed. Given the global distribution of these chemicals, this information is relevant to both the Great Lakes as well as other ecosystems.

\section{Background}

Long-term efforts to track contaminant levels were initiated by the Great Lakes Science Center (GLSC), which began monitoring contaminants in fish from Lake Michigan in 1966. In 1977, the GLSC (then called the Great Lakes Fishery Laboratory) in cooperation with the united States Environmental Protection Agency (USEPA) Great Lakes National Program Office (GLNPO) expanded monitoring to include all of the Great Lakes to address basinwide contamination problems. The GLSC Center participated in this program through 2003 under the auspices of a USEPA/GLNPO and, most recently, a United States Geological Survey (USGS) GLSC Cooperative Agreement (USEPA/USGS 1977). The distribution of chlorinated hydrocarbons in Great Lakes fish is discussed elsewhere (e.g., Giesy et al. 2002; Kannan et al. 2000a, 2000b).

In the basin, levels of many contaminants tend to be lowest in fish from Lakes Superior and Erie and highest in Lakes Michigan and Ontario because of the generally larger loadings from agricultural, municipal, industrial, and airborne sources. 


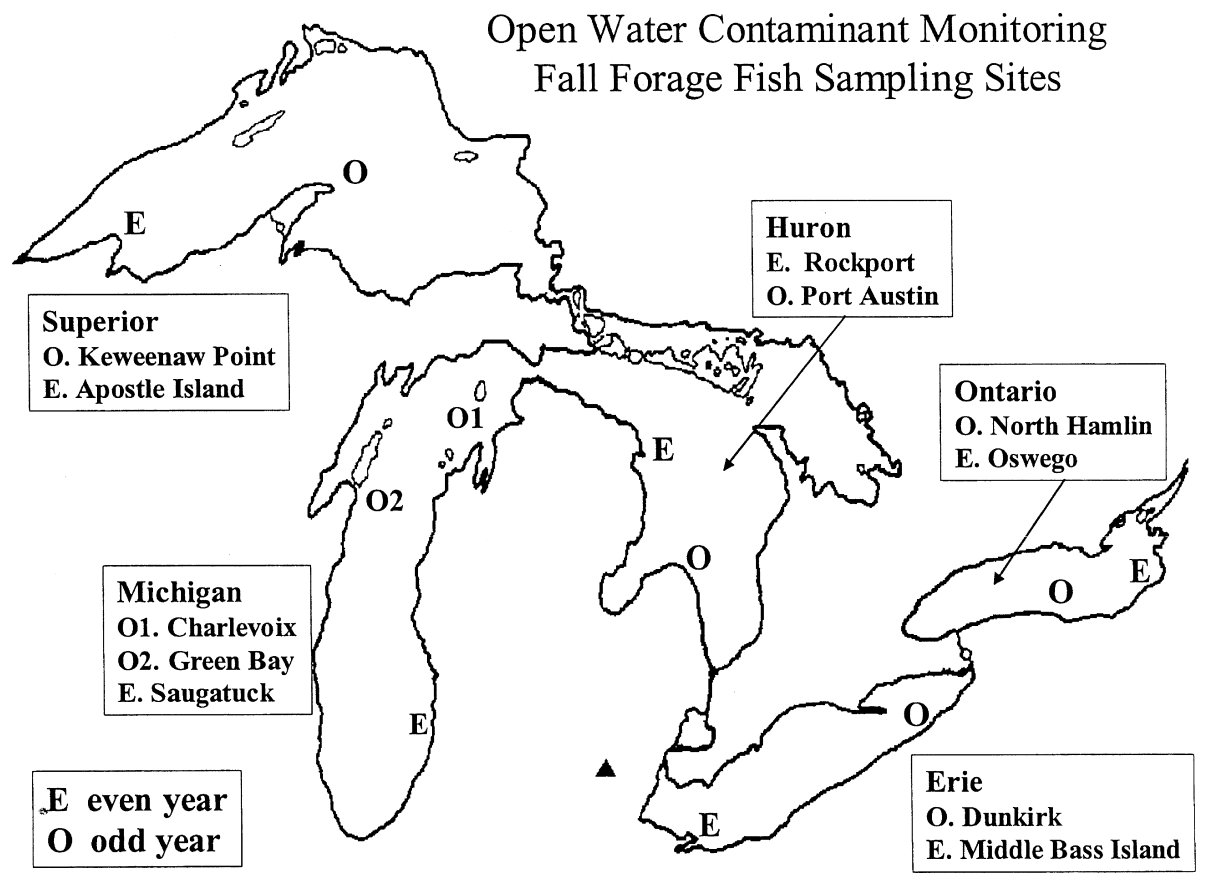

Fig. 1. Sampling sites for fall predator fish. Lake trout were sampled in most lakes, except for walleye in Lake Erie
There are a few notable exceptions to this generalization, e.g., toxaphene levels have been higher in Lake Superior relative to the other lakes. Large decreases observed in levels of DDT, PCBs, and other contaminants in the 1970s and 1980s (DeVault et al. 1985, 1986, 1996) followed soon after restrictions or bans on chemical use and manufacture. For example, DDT use was banned in 1969 to 1970 . PCBs were placed under voluntary control in 1971, and manufacturing was banned in 1977. Toxaphene use was banned in 1982. Most uses of aldrin and dieldrin, which were widely used from the 1950s to the early 1970s, were banned in 1975, and these chemicals are no longer produced in or imported into the United States (USEPA 1980), and commercial use of chlordane was banned in 1988. However, contaminant levels may no longer be decreasing, or may be decreasing so slowly that levels appear to be static (Borgmann and Whittle 1983; Suns et al. 1993; Hebert et al. 1994; De Vault et al. 1986). Concentration trends can significantly vary by site and contaminant, e.g., Borgmann and Whittle (1991) showed marked gradients of some contaminants in Lake Ontario; thus, site-specific data are needed. Also, because contaminant levels can change dramatically from year to year, lengthy records are needed to discern long-term trends.

\section{Methods}

\section{Sampling and Chemical Analysis}

Sampling locations and protocols for fish collection and methods for contaminant extraction from tissues followed methods described in DeVault et al. (1985, 1986, 1996). In brief, 10 sites, 2 for each lake, were selected in 1977 to represent United States-held open water areas of the 5 Great Lakes, all sites being in or near deep water (Fig. 1). We also reported on data collected in 1991 and 1993 at a third Lake Michigan site (Charlevoix). Because of the lakes' size, sites were balanced between those with and without influences from major tributaries and industries. Beginning in 1982, sites were sampled in alternate years (Table 1), A top predator fish in each Great Lake was sampled, specifically, lake trout (Salvelinus namaycush) from Lakes Superior, Michigan, Huron, and Ontario, and walleye (Sander vitreus) from Lake Erie. Same-size fish were collected at the same locations for 10 years in continuation of the previous 10-year study. In most cases, 10 composite samples, representing 50 fish from each site and each year that met length specifications, were analyzed.

In brief, the analysis procedure was as follows: A 10-g subsample was taken from each homogenized composite of five whole fish; analytes were solvent-extracted from fish tissue; lipids were removed by gel permeation chromatography; and analytes were separated by column chromatography. Gas chromatography-mass spectroscopy (GC-MS) analyses were performed in negative chemical-ionization mode using selective-ion monitoring, a Hewlett Packard Model 5890 GC/MS, and a DB-5 $30 \mathrm{~m} \times 0.25 \mathrm{~mm}$ i.d. $\times 0.25-\mu \mathrm{m}$ thickness capillary column according to the methods described by Schmidt and Hesselberg (1992) and Schmidt (1997). Blanks, spikes, recoveries, and duplicates were performed for each batch of 10 samples. Target compounds were not detectable in blanks. Surrogate spike recoveries were $\approx 90 \%$, and duplicate sample analyses agreed within $\pm 15 \%$. Extensive quality assurance and quality control, including analysis of audit samples, was used to guarantee data comparability through time and across laboratories. Method detection limits (MDLs) for $99 \%$ confidence, defined as three times the standard deviation of seven replicates of a procedural blank spiked with a very low level of analyte (Keith 1991), are listed in Table 1. To achieve a lower MDL for toxaphene in Lake Erie, we doubled the amount of fish and further decreased the extract to $0.5 \mathrm{ml}$.

Fish tissue was analyzed for the following contaminants: PCBs (both total and individual congeners), total DDT ( $\mathrm{p}, \mathrm{p}^{\prime}$-DDT, $\mathrm{p}, \mathrm{p}^{\prime}$ DDE, and $\mathrm{p}, \mathrm{p}^{\prime}$-DDD), chlordanes (cis-chlordane, trans-chlordane, oxychlordane, trans-nonachlor, cis-nonachlor, and heptachlor epoxide B), aldrin, dieldrin, endrin, lindane, mirex, and toxaphene (polychlorinated camphene mixture). trans-Chlordane data were measured during 1991 to 1993 but not during 1994 to 1998. Total PCBs, total DDTs, total chlordane, and total toxaphene were calculated according to the methods in Schmidt and Hesselberg (1992) and Schmidt (1997). Total chlordane did not include trans-chlordane 
Table 1. MDLs for target compounds ${ }^{\mathrm{a}}$

\begin{tabular}{llllc}
\hline \multicolumn{2}{l}{ PCBs: chlorination level } & & \multicolumn{2}{l}{ Pesticides and other organochlorines } \\
\cline { 1 - 1 } Compound & MDL (ng/g) & & Compound & MDL (ng/g) \\
\hline Tri- & 4 & & Pentachlorobenzene & 0.15 \\
Tetra- & $0.2-25$ & & Hexachlorobenzene & 1 \\
Penta- & $0.03-6$ & & Octachlorostyrene & 0.5 \\
Hexa- & $0.01-0.1$ & & p,p-DDT & 40 \\
Hepta- & $0.02-0.1$ & & p,p-DDE & 12 \\
Octa- & $0.04-0.3$ & & P,p-DDD & 70 \\
Nona- & $0.05-0.2$ & & Heptachlor epoxyde & 10 \\
Deca- & 0.04 & & Oxychlordane & 2 \\
& & Chlordane & 2 \\
& & Cis-nonachlor & 0.5 \\
& & Trans-nonachlor & 3 \\
& & Dieldrin & 0.5 \\
& & Endrin & 0.5 \\
& & Aldrin & 3.5 \\
& & Lindane & 1 \\
& & Mirex & $25 / 100$ & $(1)$ \\
\hline
\end{tabular}

${ }^{\mathrm{a}}$ For total toxaphene: Lake Erie MDL $=25 \mathrm{ng} / \mathrm{g}$; other lakes $=100$ $\mathrm{ng} / \mathrm{g}$.

MDLs = method detection limits.

because it was only measured from 1991 to 1993 . Total DDT did not include $p, p^{\prime}$-DDD because it was not measured in Lake Superior before 1993, and it was not measured at Port Austin (Lake Huron) in 1991. Total PCBs did not include congeners nos. 81/87,123, and 167 because they were only measured from 1994 to 1998 . PCB congener numbering was done according to Ballschmiter and Zell (1980). All concentrations in the present article (including MDLs) are reported on a wet-weight basis.

\section{Data Analysis}

Analyses emphasized total PCBs, total dioxin-like PCBs, total DDTs, total chlordane (sum of cis-chlordane, oxychlordane, trans-nonachlor, cis-nonachlor, and heptachlor epoxide B), dieldrin, and toxaphene. The dioxin-like PCB congeners were selected for analysis because they are the ones primarily associated with PCB toxicity. The toxic equivalent index (TEQ), which represents toxicity because of the binding of the Ah receptor, is expressed in 2,3,7,8-tetrachlorodibenzop-dioxin equivalents for the PCB mixture by summing weighted concentrations of 11 congeners (nos. 77, 81, 105, 114, 118, 123, 126, $156,157,167,189)$ using the toxic equivalency factor (TEF) weights for humans (World Health Organization, 1997) and is called "TEQ(11)" in this article. Of these, no. 126 was the most toxic congener, and no. 105 was the most abundant congener. Congener 169 , also considered dioxin-like, was not measured. Because only the most recent (1994 to 1998) period included PCB congeners nos. 81/87, 123 and 167, for trending purposes, dioxin-like PCBs excluding these congeners were also calculated and called "TEQ(8)."

Because contaminant trends in each lake differ from one another, analyses were performed individually by site. Differences between means, variances, and trends between site pairs within a lake were evaluated. Trends in contaminant concentrations in the earlier (1970 to 1991) data have been presented as a first-order (exponential) decrease (DeVault et al. 1985, 1986, 1996). Here we augment this approach using several models to represent the decreases in concentration during the extended (1970 to 1998) data record. First, we used a first-order model but add an asymptote,

$$
\mathrm{C}_{\mathrm{t}}=\mathrm{C}_{1} \exp \left(-\mathrm{k}_{1} \mathrm{t}\right)+\mathrm{C}_{0}
$$

where $\mathrm{C}_{\mathrm{t}}=$ concentration in fish $(\mathrm{ng} / \mathrm{g}), \mathrm{C}_{1}=$ the declining portion of the concentration $(\mathrm{ng} / \mathrm{g}), \mathrm{k}_{1}=$ first-order rate constant $\left(\mathrm{yr}^{-1}\right), \mathrm{t}=$ year from start of the decrease in the available record, and $\mathrm{C}_{0}=$ an irreducible or baseline concentration (ng/g). Next, we used a similar model but with two first-order processes,

$$
\mathrm{C}_{\mathrm{t}}=\mathrm{C}_{1}\left[\mathrm{f} \exp \left(-\mathrm{k}_{1} \mathrm{t}\right)+(1-\mathrm{f}) \exp \left(-\mathrm{k}_{2} \mathrm{t}\right]+\mathrm{C}_{0},\right.
$$

where $\mathrm{f}=$ fraction of $\mathrm{C}_{1}$ attributable to the slow process (and $1-\mathrm{f}=$ fraction attributable to the fast process), $\mathrm{k}_{2}=$ first-order rate constant for the fast process. Equation 2 reflects up to three contaminant sources. Two of the sources exponentially decrease at fast and slow first-order rates. Eventually, the slow process dominates the fast process. As these sources become depleted, concentrations eventually approach an irreducible level, $\mathrm{C}_{0}$, because of the presence of a third, stable contaminant source. Similar models have been used by Stowe et al. $(1994,1995)$ for PCB data in Lake Michigan.

Parameters $\mathrm{C}_{0}, \mathrm{C}_{1}, \mathrm{f}, \mathrm{k}_{1}$, and $\mathrm{k}_{2}$ were estimated to best fit the observations using a quasi Newton gradient search method to minimize deviations between predicted and observed concentrations. Because of the nonnormal distribution of concentrations, data were logtransformed for optimization. Also, estimated parameters were constrained to be $\geq 0$, $\mathrm{f}$ was constrained $\leq 1$, and a single compartment model was forced if $\mathrm{k}_{1} \approx \mathrm{k}_{2}$, if $\mathrm{f}$ were near 1 or 0 , or if the estimated uncertainty of $\mathrm{k}_{2}$ were large relative to the parameter itself. For completeness, we estimated both models for each contaminant and lake. Additionally, zero intercepts $\mathrm{C}_{0}$ were allowed in either model, thus eliminating the stable (third) source. Model results were plotted using a log-linear scale, which yields a straight line if a single compartment first-order model with no intercept applies. We selected the most parsimonious model that fit the data and that had stable and statistically significant coefficients.

\section{Results}

A summary of selected physical and chemical data for 1991 to 1998 GC-MS contaminant analyses of annual fall predator fish is listed in Table 2. Not shown are several chemicals that are now below MDLs in most fish tissue samples, including aldrin, endrin, and lindane.

\section{Within-Lake Differences}

The 1991 to 1998 data showed no statistically significant differences in variances among concentrations collected at the paired sites at each lake ( $F$ tests $p>0.05$ ). Two-sample Student $t$ tests showed that mean concentrations may have differed between sites in two lakes for a few contaminants. In Lake Huron, dieldrin measurements were $33 \%$ higher at Port Austin compared with Rockport $(p=0.04)$, and toxaphene was $64 \%$ higher but again with marginal significance $(p=0.06)$. Notably, levels of dieldrin and toxaphene dramatically decreased during this time period, and the site differences appear simply because of the staggered sampling. In Lake Michigan, Saugatuck tended to have higher concentrations than Sturgeon Bay for total PCBs $(p=0.10,29 \%$ difference) and dieldrin ( $p=0.09,42 \%$ difference), but the 


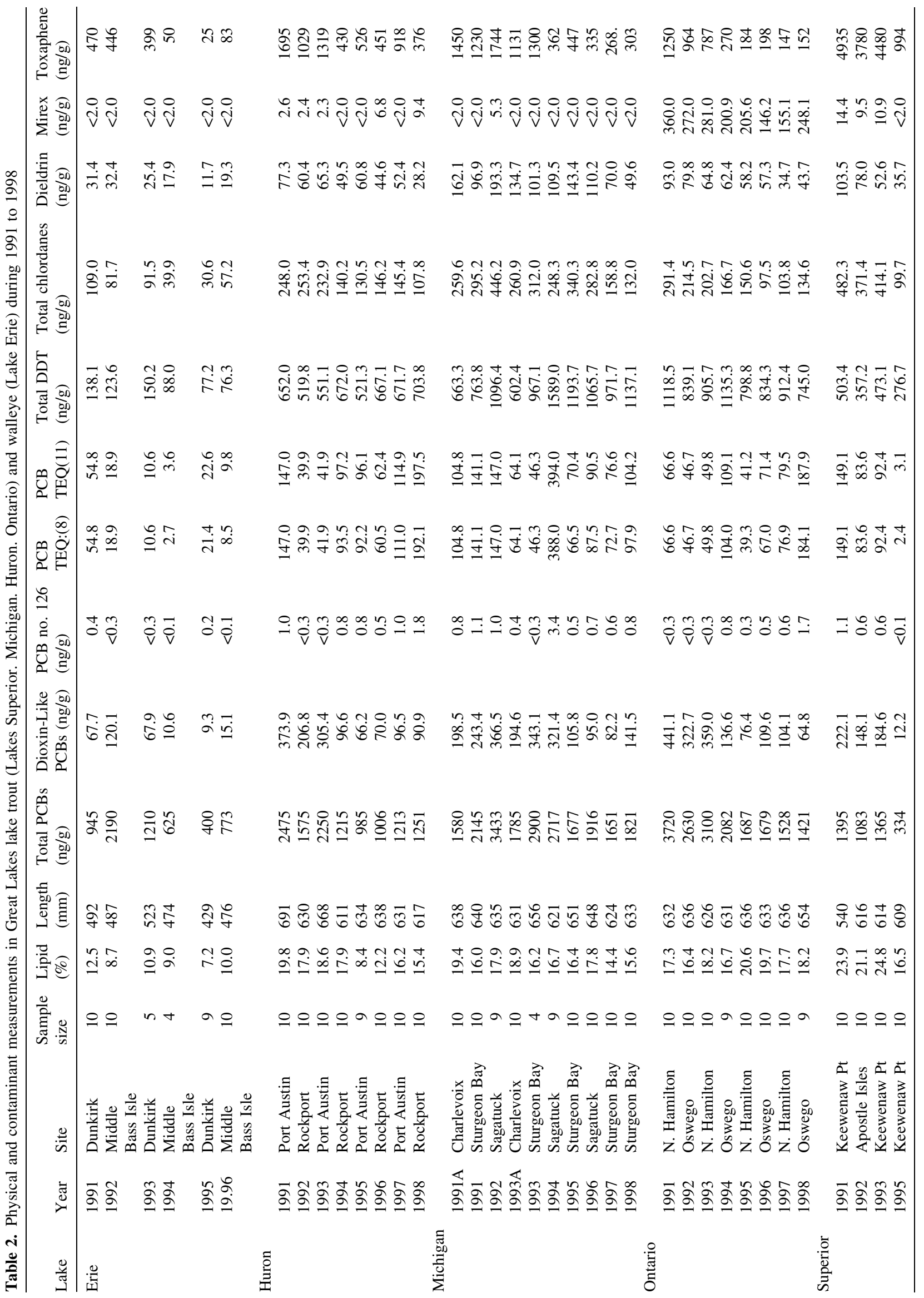




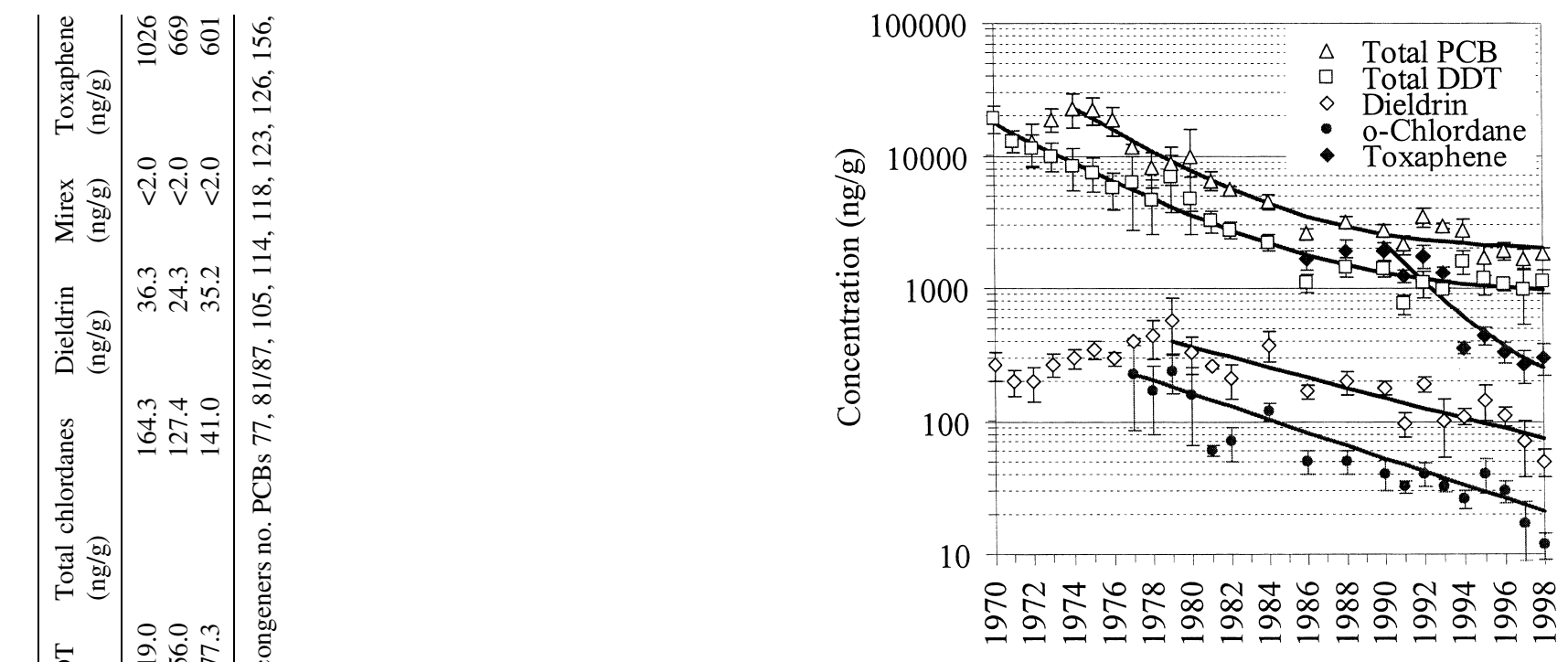

Fig. 2. Long-term trends of contaminants in lake trout from Lake Michigan. Plots show mean concentration and SDs, trend lines from first-order models

statistical significance again was marginal. No other contaminants showed statistically significant or near-significant differences in mean concentrations within site pairs in these or other lakes. With some caveats, this simplifies the analysis because the data from pairs of sites can be pooled. It should be noted that spatial differences within a lake may be significant in the short-term, e.g., differences in PCB levels in fish collected from Sturgeon Bay and Saugatuck were found to be significantly different in 1994 to 1995 (Madenjian 1989).

\section{Trends}

Initially, trends in each lake are analyzed by combining earlier measurements (De Vault et al. 1996) with the data collected here. Figures 2 to 6 show annual mean levels (and SDs) of total PCB, total DDT, dieldrin, oxychlordane, and toxaphene, along with long-term trends estimated using the first-order models. Parameters and statistics, including fit $\left(R^{2}\right)$ and halflife $\left(t_{1 / 2}\right)$, of the single-compartment first-order model (Equation 1) are listed in Table 3. When the three-compartment model (Equation 2) was used, parameter uncertainty of coefficient $\mathrm{k}_{2}$ was large and $R^{2}$ increased only marginally. Also, there was a direct interaction or compensation between the incorporation of the second exponential term $\left(\mathrm{k}_{2}\right)$ and the irreducible constant $\left(\mathrm{C}_{0}\right)$, and, generally, the use of $\mathrm{k}_{2}$ forced $\mathrm{C}_{0}$ to zero. Thus, the more complex model appears to be over specified for the amount and nature (scatter) of the data available. Models using a single first-order process and often a constant term gave robust and statistically significant $(p<$ 0.05 ) coefficients for all contaminants at all sites with one exception (dieldrin in Lake Superior, discussed further below). Moreover, the more parsimonious models yield $t_{1 / 2}$ that were more comparable across the five lakes.

After discussing contaminant trends by lake, we review results by contaminant class. The percentage changes in con- 


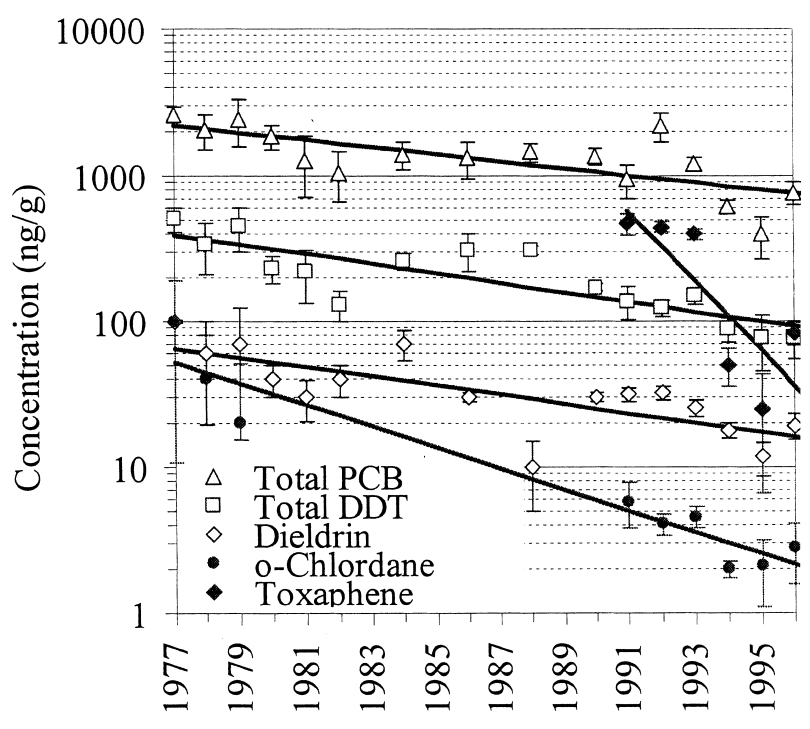

Fig. 3. Long-term trends of contaminant in walleye from Lake Erie. Otherwise as in Figure 2

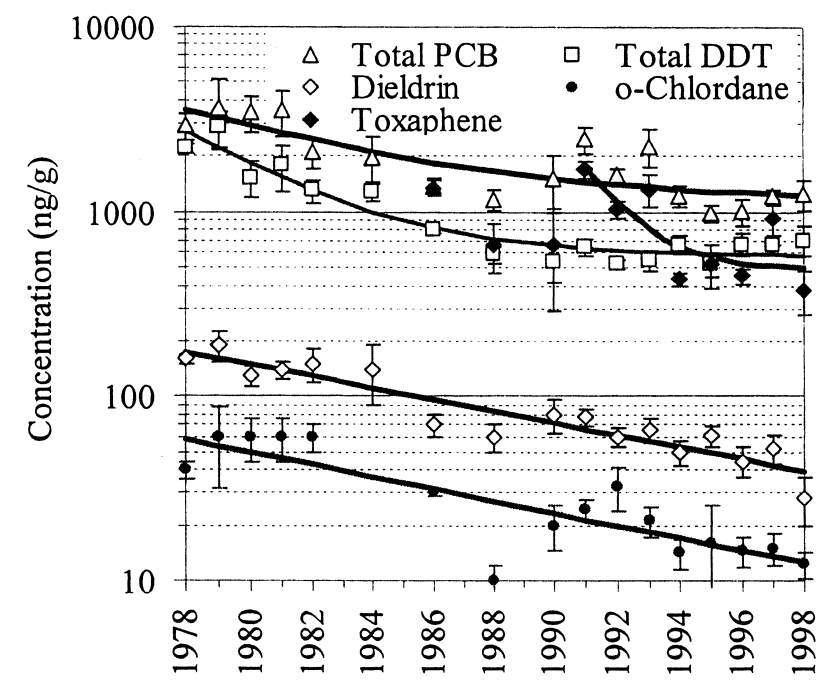

Fig. 4. Long-term trends of contaminants in lake trout from Lake Huron. Otherwise as in Figure 2

centrations during the two most recent 4-year periods (1991 to 1994 and 1995 to 1998), are listed in Table 4.

\section{Lake Michigan}

Contaminant trends in lake trout in Lake Michigan are depicted in Figure 2. Lake Michigan fish have had, and continue to have, some of the highest concentrations of organochlorine contaminants in the basin, and the monitoring record is most complete for this lake. For these reasons and to discuss the modeling in more depth, results for this lake are presented in some detail.

PCBs. PCB levels in Lake Michigan (along with Lake Ontario) are the highest in the Great Lakes. Concentrations decreased from the maximum levels of $23,000 \pm 5000 \mathrm{ng} / \mathrm{g}$

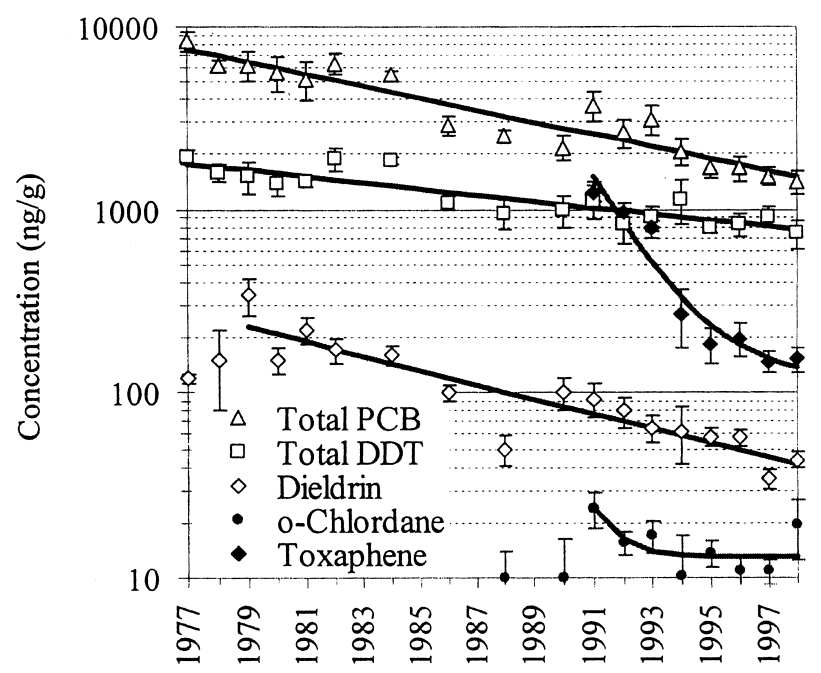

Fig. 5. Long-term trends of contaminants in lake trout from Lake Ontario. Otherwise as in Figure 2

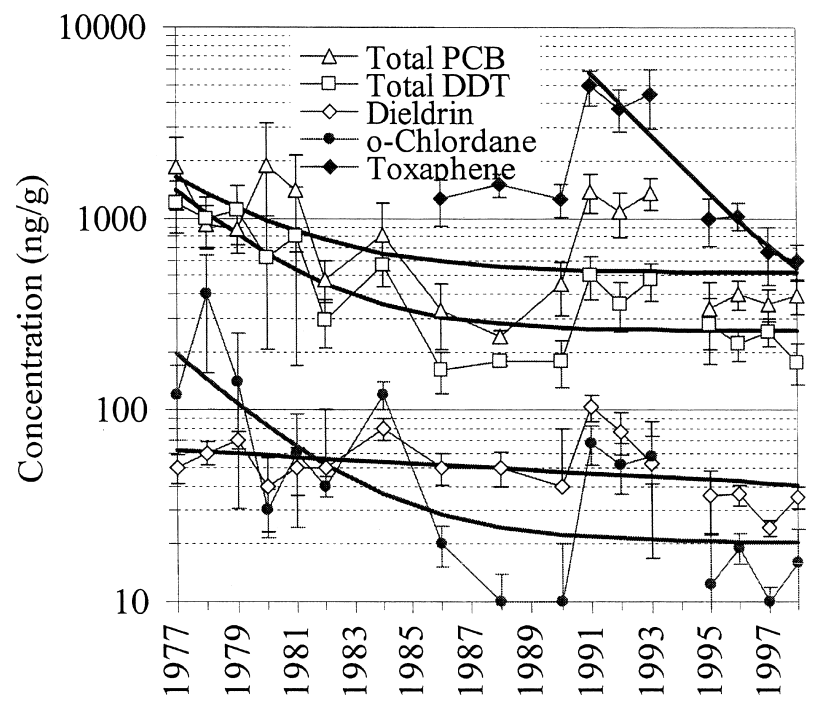

Fig. 6. Long-term trends of contaminants in lake trout from Lake Superior. Otherwise as in Figure 2

observed in 1975 to $1800 \pm 170 \mathrm{ng} / \mathrm{g}$ in 1998 , and levels decreased below the 2000-ng/g Food and Drug Adminstration (FDA) action level (highest legally permitted residue level for a particular contaminant in food) in 1996. PCB levels continue to decrease albeit at a slower rate. The first-order model, which obtained a very high fit $\left(R^{2}=0.96\right)$, has rate constants of $0.22 \pm 0.05 \mathrm{y}^{-1}$, respectively, equivalent to a half-life $\left(\mathrm{t}_{1 / 2}\right)$ of 3.2 years (Table 3 ) with an large irreducible or "background" level of PCBs $\left(\mathrm{C}_{0}\right)$ of $1894 \mathrm{ng} / \mathrm{g}$. Compared with De Vault et al. (1996), who obtained a $t_{1 / 2}=5.8$ years and $R^{2}=0.86$, these results provide a higher fit and, more importantly, quantify that the rate of PCB removal in Lake Michigan is still decreasing but only very slowly because the irreducible component now makes up nearly all of the PCBs, e.g., mean PCB levels will fall only to $1900 \mathrm{ng} / \mathrm{g}$ in 2010. With 
Table 3. Parameters of the first-order models for five contaminants in each lake

\begin{tabular}{|c|c|c|c|c|c|c|c|c|}
\hline Lake & Parameter & Starting year & $\mathrm{C}_{0}(\mathrm{ng} / \mathrm{g})$ & $\mathrm{C}_{1}(\mathrm{ng} / \mathrm{g})$ & $\mathrm{k}_{1}\left(\mathrm{y}^{-1}\right)$ & & $\mathrm{k}_{1} \mathrm{t}_{1 / 2}(\mathrm{y})$ & $R^{2}$ \\
\hline \multirow[t]{5}{*}{ Michigan } & Total PCB & 1974 & 1894 & 21649 & 0.217 & $(0.048)$ & 3.19 & 0.96 \\
\hline & Total DDT & 1970 & 876 & 16866 & 0.183 & $(0.030)$ & 3.79 & 0.96 \\
\hline & Dieldrin & 1979 & 0 & 402 & 0.089 & $(0.012)$ & 7.82 & 0.73 \\
\hline & o-Chlordane & 1977 & 0 & 230 & 0.114 & $(0.011)$ & 6.08 & 0.83 \\
\hline & Toxaphene & 1990 & 152 & 2040 & 0.369 & $(0.059)$ & 1.88 & 0.77 \\
\hline \multirow[t]{5}{*}{ Huron } & Total PCB & 1978 & 1107 & 2478 & 0.150 & $(0.054)$ & 4.61 & 0.70 \\
\hline & Total DDT & 1978 & 571 & 2165 & 0.268 & $(0.082)$ & 2.58 & 0.87 \\
\hline & Dieldrin & 1978 & 0 & 175 & 0.074 & $(0.007)$ & 9.33 & 0.88 \\
\hline & o-Chlordane & 1978 & 0 & 58 & 0.077 & $(0.013)$ & 9.06 & 0.75 \\
\hline & Toxaphene & 1991 & 484 & 1266 & $0.668^{\mathrm{a}^{* * *}}$ & $(0.433)$ & 1.04 & 0.70 \\
\hline \multirow[t]{5}{*}{ Erie } & Total PCB & 1977 & 0 & 2208 & 0.056 & $(0.014)$ & 12.40 & 0.61 \\
\hline & Total DDT & 1977 & 0 & 397 & 0.077 & $(0.014)$ & 9.06 & 0.70 \\
\hline & Dieldrin & 1977 & 0 & 65 & 0.073 & $(0.017)$ & 9.44 & 0.69 \\
\hline & o-Chlordane & 1977 & 0 & 53 & 0.169 & $(0.018)$ & 4.11 & 0.55 \\
\hline & Toxaphene & 1991 & 0 & 572 & 0.553 & $(0.201)$ & 1.25 & 0.77 \\
\hline \multirow[t]{5}{*}{ Ontario } & Total PCB & 1977 & 0 & 7489 & 0.076 & $(0.007)$ & 9.10 & 0.89 \\
\hline & Total DDT & 1977 & 0 & 1773 & 0.039 & $(0.005)$ & 17.68 & 0.74 \\
\hline & Dieldrin & 1979 & 0 & 227 & 0.090 & $(0.011)$ & 7.68 & 0.80 \\
\hline & o-Chlordane & 1991 & 13 & 11 & 1.178 & $(0.321)$ & 0.59 & 0.57 \\
\hline & Toxaphene & 1991 & 120 & 1397 & 0.624 & $(0.069)$ & 1.11 & 0.90 \\
\hline \multirow[t]{5}{*}{ Superior } & Total PCB & 1977 & 516 & 1140 & 0.297 & $(0.098)$ & 2.33 & 0.32 \\
\hline & Total DDT & 1977 & 257 & 1165 & 0.357 & $(0.074)$ & 1.94 & 0.79 \\
\hline & Dieldrin & 1977 & 0 & 62 & $0.020^{\mathrm{a}^{*}}$ & $(0.033)$ & 35.09 & 0.06 \\
\hline & o-Chlordane & 1977 & 20 & 174 & 0.340 & $(0.092)$ & 2.04 & 0.44 \\
\hline & Toxaphene & 1991 & 185 & 5641 & 0.391 & $(0.043)$ & 1.77 & 0.84 \\
\hline
\end{tabular}

${ }^{\mathrm{a}}$ All values of $\mathrm{k}_{1}$ are highly statistically significant at the $p=0.01$ level, except for $*(p=0.07)$ and $* *(p=0.03)$. DDT $=$ dichloro-diphenyl-trichloroethane.

$\mathrm{PCB}=$ polychlorinated biphenyl.

Table 4. Percentage decreases in fish lipid, length, and contaminant concentrations comparing 1991 to 1994 and 1995 to 1998 periods using $4-$ year averages $(\%)$ and statistical significance of change ( $p$ value in parentheses) based on 1-sided equal variance Student $t$-tests

\begin{tabular}{lrrrcrrrrr}
\hline Lake & \multicolumn{1}{c}{ Lipid } & \multicolumn{1}{c}{ Length } & \multicolumn{1}{c}{ Tot. PCB } & Dioxin-Like PCBs & Total DDT & Total Chlordanes & Dieldrin & Mirex & Toxaphene \\
\hline Erie & $17(0.18)$ & $9(0.06)$ & $64(0.14)$ & $112(0.09)$ & $\mathbf{4 4}(0.04)$ & $54(0.10)$ & $49(0.06)$ & $\mathrm{b}$ & $117(0.06)$ \\
Huron & $\mathbf{3 5}(0.01)$ & $3(0.16)$ & $\mathbf{5 1}(0.02)$ & $\mathbf{1 0 1}(0.02)$ & $-7(0.24)$ & $\mathbf{4 9}(0.01)$ & $30(0.06)$ & $\mathrm{b}$ & $\mathbf{6 5}(0.05)$ \\
Michigan & $9(0.07)$ & $0(0.38)$ & $\mathbf{3 1}(0.05)$ & $\mathbf{8 2}(0.00)$ & $-14(0.23)$ & $27(0.10)$ & $34(0.08)$ & $\mathrm{b}$ & $\mathbf{1 0 1}(0.00)$ \\
Ontario & $-\mathbf{1 1}(0.02)$ & $-1(0.08)$ & $\mathbf{5 8}(0.01)$ & $\mathbf{1 1 2}(0.01)$ & $\mathbf{1 9}(0.04)$ & $\mathbf{5 7}(0.01)$ & $\mathbf{4 3}(0.01)$ & $\mathbf{3 8}(0.03)$ & $\mathbf{1 3 1}(0.01)$ \\
Superior & $\mathbf{6 4}(0.00)$ & $-7(0.06)$ & $\mathbf{1 2 0}(0.00)$ & $\mathbf{1 9 3}(0.00)$ & $\mathbf{6 6}(0.00)$ & $\mathbf{1 1 3}(0.00)$ & $\mathbf{8 6}(0.01)$ & $\mathbf{1 6 2}(0.00)$ & $\mathbf{1 5 2}(0.00)$ \\
Overall & $\mathbf{1 7}(0.02)$ & $-2(0.29)$ & $\mathbf{5 5}(0.00)$ & $\mathbf{1 0 5}(0.00)$ & $5(0.39)$ & $\mathbf{5 3}(0.00)$ & $\mathbf{4 4}(0.01)$ & $54(0.36)$ & $\mathbf{1 0 2}(0.00)$ \\
\hline
\end{tabular}

${ }^{a}$ Negative change (-) indicates increase in concentration. Statistically significant $(p \leq 0.05)$ changes in bold.

${ }^{\mathrm{b}}$ Insufficient number of observations above MDL.

MDL $=$ method dectection limit.

PCBs $=$ polychlorinated biphenyls .

DDT $=$ dichloro-diphenyl-trichloroethane.

this model, PCB levels will not decrease below $1894 \mathrm{ng} / \mathrm{g}$ $\left(=\mathrm{C}_{0}\right)$; thus, levels will continue to hover around the FDA action level. Of course, extrapolations can be faulty, e.g., Figure 2 suggests a faster decrease when only the 1992 to 1998 data are considered, but this period is too short for trend analysis. Overall, the PCB trend in Figure 2 appears robust.

DDT. Total DDT levels in fish in Lake Michigan, the highest among the Great Lakes, follow trends similar to PCBs. In this case, however, the peak DDT levels likely occurred before 1970, before the monitoring record. Again, although the $\mathrm{t}_{1 / 2}$ is relatively fast (3.8 years), current levels are largely controlled by the irreducible concentration $\left(\mathrm{C}_{0}=876 \mathrm{ng} / \mathrm{g}\right)$, and future decreases will be both slow and small. For example, total DDT levels are predicted to decrease by only $92 \mathrm{ng} / \mathrm{g}$ from 1998 levels to reach $887 \mathrm{ng} / \mathrm{g}$ in 2010 and after another 10 years levels will decrease only to $877 \mathrm{ng} / \mathrm{g}$, essentially reaching $\mathrm{C}_{0}$. No further decreases are predicted. The three-compartment model gave similar results. Although the model fit was very high $\left(R^{2}=0.96\right)$, such extrapolations can be erroneous. Still, the key result, a declining rate of DDT removal, is clear.

Pesticides. Oxychlordane levels peaked in 1979 or possibly earlier (data before 1977 are unavailable), and its current $t_{1 / 2}$ is 6.1 years. Dieldrin levels also peaked in 1979, 
Table 5. 1991 to 1998 average 2, 3, 7, 8 TCDD (TEQ)s by lake and apportionment by PCB congener

\begin{tabular}{|c|c|c|c|c|c|c|c|c|c|c|c|}
\hline & & \multicolumn{2}{|l|}{ Erie } & \multicolumn{2}{|l|}{ Huron } & \multicolumn{2}{|c|}{ Michigan } & \multicolumn{2}{|c|}{ Ontario } & \multicolumn{2}{|c|}{ Superior } \\
\hline & & Mean & SD & Mean & SD & Mean & SD & Mean & SD & Mean & SD \\
\hline Dioxin-like PCBs-TEQ & $(\mathrm{pg} / \mathrm{g})$ & 20 & $(18)$ & 100 & $(54)$ & 134 & $(111)$ & 82 & $(48)$ & 52 & $(57)$ \\
\hline \multicolumn{12}{|l|}{ Apportionment of TEQ } \\
\hline $3,3^{\prime}, 4,4^{\prime}-\mathrm{TCB}$ (PCB no. 77$)^{*}$ & $(\%)$ & 0.2 & $(0.3)$ & 0.4 & $(0.3)$ & 0.4 & $(0.2)$ & 0.4 & $(0.4)$ & 0.3 & $(0.6)$ \\
\hline 3,4,4'5-TCB (no. 81) & $(\%)$ & 6.9 & (9.4) & 2.0 & (1.7) & 2.0 & $(2.5)$ & 2.4 & (2.3) & 10.3 & (11.2) \\
\hline $3,3^{\prime}, 4,4^{\prime}, 5-\mathrm{PeCB}$ (no. 126 ) & $(\%)$ & 36.5 & $(41.5)$ & 64.6 & $(32.7)$ & 66.2 & $(24.6)$ & 48.2 & $(40.6)$ & 42.3 & $(39.7)$ \\
\hline $3,3^{\prime}, 4,4^{\prime}, 5,5^{\prime}-\mathrm{HxCB}($ no. 169$)$ & $(\%)$ & - & - & - & - & - & - & - & - & - & - \\
\hline $2,3,3^{\prime}, 4,4^{\prime}-\mathrm{PeCB}$ (no. 105) & $(\%)$ & 8.3 & (7.6) & $(7.2)$ & $(7.0)$ & 6.8 & $(5.7)$ & 9.5 & (7.8) & 6.8 & $(4.1)$ \\
\hline $2,3^{\prime}, 4,4^{\prime}, 5-\mathrm{PeCB}$ (no. 114 ) & $(\%)$ & 7.9 & $(9.7)$ & 3.2 & (2.3) & 3.0 & $(1.8)$ & 4.1 & $(2.5)$ & 5.7 & $(5.0)$ \\
\hline $2,3^{\prime}, 4,4^{\prime}, 5-\mathrm{PeCB}($ no. 118$)$ & $(\%)$ & 16.4 & $(16.5)$ & 14.0 & $(16.0)$ & 12.9 & $(12.4)$ & 20.2 & (19.2) & 12.5 & $(5.8)$ \\
\hline $2,3^{\prime}, 4,4^{\prime}, 5^{\prime}-\mathrm{PeCB}($ no. 123 ) & $(\%)$ & 0.0 & $(0.0)$ & 0.0 & $(0.0)$ & 0.0 & $(0.0)$ & 0.0 & $(0.0)$ & 0.0 & $(0.0)$ \\
\hline $2,3,3^{\prime}, 4,4^{\prime}, 5-\mathrm{HxCB}($ no. 156$)$ & $(\%)$ & 20.4 & $(12.9)$ & 7.4 & (6.9) & 6.9 & $(4.2)$ & 12.4 & (9.9) & 19.0 & $(14.6)$ \\
\hline $2,3,3^{\prime}, 4,4^{\prime}, 5^{\prime}-\mathrm{HxCB}$ (no. 157 ) & $(\%)$ & 2.8 & $(3.0)$ & 1.2 & (1.7) & 1.6 & $(1.8)$ & 2.6 & (3.9) & 2.1 & $(1.6)$ \\
\hline $2,3^{\prime}, 4,4^{\prime}, 5,5^{\prime}-\mathrm{HxCB}$ (no. 167 ) & $(\%)$ & 0.5 & $(0.8)$ & 0.1 & $(0.1)$ & 0.1 & $(0.1)$ & 0.1 & $(0.2)$ & 0.8 & $(1.0)$ \\
\hline $2,3,3^{\prime}, 4,4^{\prime}, 5,5^{\prime}-\mathrm{HpCB}$ (no. 189) & $(\%)$ & 0.1 & $(0.1)$ & 0.0 & $(0.0)$ & 0.0 & $(0.0)$ & 0.0 & $(0.0)$ & 0.1 & $(0.1)$ \\
\hline
\end{tabular}

$\mathrm{TEQ}=$ toxic equivalency quotient.

and the decrease is slightly slower, e.g., $\mathrm{t}_{1 / 2}=7.8$ years. In most years (especially 1992 and 1995), dieldrin levels in Lake Michigan were much higher than levels measured in the other lakes. Toxaphene levels peaked in 1990, and the decrease in concentration has been rapid; however, the short span of data do not permit robust model estimates. These three compounds (or groups) show considerable fluctuations from year to year. Most mirex levels were below MDLs.

\section{Lake Erie}

In this lake, contaminant data came from walleye, a relatively lean fish (about half the fat content of the lake trout). Because sampling in the other lakes used lake trout, contaminant concentrations were not directly comparable, e.g., concentrations in walleye were generally much lower than those in trout. Interestingly, none of the fitted trends had an irreducible component; variation around the trend line was greater (yielding lower fits in $R^{2}$ ), and many of the contaminants showed especially rapid (but possibly temporary) decreases from 1992 to 1995 (Fig. 3). PCB levels are gradually diminishing with a much longer $t_{1 / 2}(12.4$ years than in Lake Michigan, but because there is no irreducible component, levels will continue to decrease eventually to zero. Note, however, that model fit was only moderately good $\left(R^{2}=0.61\right)$. DDT levels are decreasing somewhat more rapidly, but fluctuations above $(1986,1988)$ and below (1982) the trend line are notable. Dieldrin also shows a comparable $t_{1 / 2}(9.4$ years), again with some large variations from the long-term trend, especially a high level in 1984 corresponding to slightly larger and fattier fish (10\% lipid) for that decade, and a low level in 1995 corresponding to the lowest (7.2\%) lipid content observed. Oxychlordane levels are decreasing slightly faster in Lake Erie fish $\left(\mathrm{t}_{1 / 2}=4.1\right.$ years $)$, as in Lake Michigan, although data are scarce.

\section{Lake Huron}

Trends of most contaminants in lake trout showed considerable short-term variation (Fig. 4), although the first-order models provided good fits for total DDT and dieldrin trends $\left(R^{2}=0.87\right.$ and 0.88 , respectively). PCBs and DDT levels increased slightly from 1995 to 1998 , corresponding with a dramatic increase in lipid content (from $8 \%$ to $16 \%$ ) in fish collected during this period. PCB levels have a moderate $t_{1 / 2}$ (4.6 years) and a large irreducible level $\left(\mathrm{C}_{0}=1107 \mathrm{ng} / \mathrm{g}\right)$. Irreducible levels of DDT and toxaphene are indicated, but the significance of the latter is questionable because of the short record. DDT levels have been more or less stable from 1988 to 1998, and further decreases beyond the irreducible level $\left(\mathrm{C}_{0}=571 \mathrm{ng} / \mathrm{g}\right)$ are not predicted.

\section{Lake Ontario}

As mentioned, lake trout in Lake Ontario (along with those in Lake Michigan) showed the highest PCB levels. The firstorder models provided good fits to long-term trends, and concentrations appear to be decreasing at a steady first-order rate (Fig. 5). Single-compartment models with an irreducible level are indicated for oxychlordane and toxaphene, but the record for these two contaminants is short, and intercepts are small. The peak dieldrin level of $340 \pm 76 \mathrm{ng} / \mathrm{g}$ was measured in 1979 and corresponds to the heaviest and fattiest (lipid content $=22 \%$ ) fish sampled in this lake. Also, the 1977 to 1981 fish were smaller ( 0.50 to $0.56 \mathrm{~m}$ length) than those sampled subsequently $(0.61$ to $0.65 \mathrm{~m})$, although the lipid content was generally comparable.

Mirex. Mirex levels in Lake Ontario trout averaged $234 \pm 71 \mathrm{ng} / \mathrm{g}$ during the 1991 to 1998 period, and a gradual concentration decrease was observed, e.g., 38\% decrease from 1991 to 1994 to 1995 to 1998 averages, $p=0.03$ (Table 4). Levels consistently exceeded the 100-ng/g FDA action level. Historically, these mirex levels are similar or slightly higher than the 1977 to 1993 average of 207 ng/g at Main Duck Island near Oswego (Huestis et al. 1996), possibly because of diet changes. In contrast, mirex was infrequently detected in the other lakes, and maximum concentrations (10 to $14 \mathrm{ng} / \mathrm{g}$ in Lake Superior in 1991 to 1993 ) were much lower. 
The discovery of increased levels of mirex in Lake Ontario fish during the 1960s triggered lakewide fish consumption advisories, some of which still exist today (USEPA 2005). The use and production of mirex, also known as dechlorane and chlordecone, have been banned in North America since June 1978 (International Organisation for the Management of Chemicals 1995). Mirex has been identified as a Lakewide Management Plan critical pollutant because levels in some Lake Ontario fish continue to exceed human health standards. Most of the mirex originated from a production facility on the Niagara River. Most $(\approx 1.8 \mathrm{~kg} / \mathrm{y})$ still enters Lake Ontario from the Niagara River basin; smaller amounts $(\approx 0.9 \mathrm{~kg} / \mathrm{y})$ enter via the Oswego River, and $\approx 0.7 \mathrm{~kg} / \mathrm{y}$ of mirex leaves Lake Ontario by way of the St. Lawrence River (Huestis et al. 1996). No reliable estimates of atmospheric deposition or volatilization are available.

Although most widely known for its use as a pesticide, $\sim 75 \%$ of the mirex produced was used as a flame retardant in industrial, manufacturing, and military applications. Available sales records suggest that $>50,000$ pounds of mirex were used for this purpose in the Lake Ontario basin, and $>75,000$ pounds were used as a flame retardant in other Great Lakes basins (Huestis et al. 1996).

\section{Lake Superior}

Contaminant levels in lake trout in Lake Superior have varied tremendously with time (Fig. 6). Some of the variation may be attributable to the slightly longer and fattier fish collected in 1977 to 1981 (lipid content $=15 \%$ to $22 \%$ ) and the fattier fish collected in 1991 to 1993 (lipid content $=21 \%$ to $25 \%$ ). Most of the variation, however, is caused by changes in the diet and food web. In the late 1980s, the diet of lake trout in Lake Superior changed from relatively lean and small slimy sculpins (Cottus cogngatus) and rainbow smelt (Osmerus mordax) to larger, longer-lived, and much more lipid-heavy lake herring (Coregonus artedi; Bronte and Hoff 1999; Gallinat and Bronte 1995), as confirmed by a stable-isotope study (Whittle et al. 1997). These and other changes in the fish community in Lake Superior are discussed by Bronte et al. (2003). The herring diet dramatically increased contaminant intake and accumulation in lake trout. For example, compared with the 1986 to 1989 average, 1991 to 1993 levels increased for total PCBs by $280 \%$, total dioxins by $210 \%$, dieldrin by $70 \%$, oxychlordane by $340 \%$, and toxaphene by $230 \%$. These dietary changes appeared to have occurred earlier than 1993, as offered by Whittle et al. (1997) in explaining toxaphene trends. Both we and Swackhamer (1999) re-examined the original extracts and confirmed the increase of all contaminants during 1991 to 1993. During 1993 to 1994 , the diet began to shift again to an even leaner diet than before, which included insects and particulate matter with only large lake herring and relatively few smelt available (Bronte and Hoff 1999; Gallinat and Bronte 1995). This dramatically decreased levels of lipids and contaminants in the lake trout, e.g., 1994 to 1998 averages decreased to 1986 to 1989 averages and even more for dieldrin and toxaphene.

Because of the year-to-year fluctuations, contaminant levels in Lake Superior trout show the greatest divergence from the estimated long-term trends, and model fit was especially poor for total PCBs, dieldrin, and oxychlordane $\left(0.06 \leq R^{2}<\right.$ 0.44 ), and the model for diedrin was not statistically significant at the $p=0.05$ level. The first-order models indicate that trends in total PCBs, total DDT, and oxychlordane have been flat since 1986. However, more recent data show statistically significant decreases when 1991 to 1993 (1994 data are not available) and 1995 to 1998 data are compared (Table 4). As discussed previously, much of this is related to the large decrease in lipid content during this period $(23 \% \pm 12 \%$ to $12 \% \pm 3 \%$ using 3 - and 4-year averages) as well as to the dietary changes over this period.

Toxaphene. As noted earlier, Lake Superior has had the highest toxaphene levels in the basin, especially in 1991 when levels reached $1250 \pm 150 \mathrm{ng} / \mathrm{g}$, and also the greatest decrease, during the late 1990s (Swackhamer et al. 1999). Others have noted these high levels in Lake Superior (e.g., Kiriluk et al. 1997; Glassmeyer et al. 1997; Whittle et al. 2000; Muir et al. 2002 , 2004) in contrast to other bioaccumulative organic contaminants found at the lowest levels in Lake Superior among the Great Lakes. The reasons for increased toxaphene in Lake Superior are uncertain. We would expect roughly comparable atmospheric deposition rates. There may be other, as yet unknown, sources. Unlike other hydrophobic organic contaminants, the atmospheric balance of toxaphene is dominated by gas exchange across air-water. High concentrations in Lake Superior may result from the lake's low temperature, which decreases losses from volatilization; its lower productivity and sedimentation rate, which decreases transport to sediment; and its greater water volume (Swackhammer et al. 1999; James 2001). However, the first-order model for toxaphene in Lake Superior shows a $t_{1 / 2}$ of 1.8 years comparable with that seen in Lake Michigan but nearly double that seen in the other lakes (Table 3), so this is only a partial explanation. Also, fish collected in other northern locations (northern portions of Lakes Huron and Michigan) have not shown increased toxaphene concentrations (Whittle 2000; Muir 2002). Seasonal shifts vis-à-vis the time of sampling might cause differences, e.g., Muir (2004) found that toxaphene concentrations vary seasonally in lower tropic level organisms, reflecting shifts in the composition of the zooplankton community. Seasonal sampling of a range of organisms might shed more light on toxaphene in Lake Superior.

\section{Persistence by Chemical}

Levels in the top fish predators in the basin continued to gradually decrease for most contaminants, with $t_{1 / 2}$ from approximately 2 to 9 years for most contaminants in most lakes. Trends fitted to the data showed important differences between lakes and chemicals.

PCBs. The half-life of total PCBs ranged from 3.2 (Lake Michigan) to 12.4 (Huron) years, not including Lake Superior, which poorly fit the first-order model $\left(2.3\right.$ years, $\left.R^{2}=0.32\right)$. The range is much smaller, however, when lakes showing an 
irreducible concentration (i.e., Michigan, Huron, Superior) are separated ( $\mathrm{t}_{1 / 2}$ from 2.3 to 4.6 years) from lakes not having this term (Erie and Ontario $t_{1 / 2}$ from 9.1 to 12.4 years ). These results differ from previous analyses that showed little change in PCB concentrations in Lake Erie since 1982 and in Lakes Superior, Michigan, Huron, and Ontario since 1986 or 1988 (De Vault et al., 1996). The first-order models and trend plots suggest that concentrations are declining, albeit at a decreasing rate, in fish in the three more northern lakes. At present, concentrations are only very slowly decreasing in Lakes Michigan and Huron because of the relatively high irreducible levels of 1820 and $1107 \mathrm{ng} / \mathrm{g}$, respectively. Trends were highly consistent for Lakes Michigan and Ontario but much less definitive for Lakes Huron, Erie, and Superior during the late 1980s and 1990s when concentrations decreased below $\sim 1500$ $\mathrm{ng} / \mathrm{g}$, and year-to-year variability was sizeable. As discussed later, this variation may reflect several influences, e.g., changes in fish range and diet and sampling and analytical variations. We speculate that PCB concentrations in Lakes Michigan and Ontario will also increase in variability and possibly plateau as levels decrease to $\leq 1000$ to $1500 \mathrm{ng} / \mathrm{g}$. Also, trends may vary for individual components of the PCB mixture (discussed below).

Comparing recent trends of PCBs using 4-year averages (Table 4), total PCB levels have decreased in all lakes, sometimes dramatically, although differences were not statistically significant for Lakes Erie and Michigan. It should be recognized that only 8 years of data do not allow a statistically robust analysis of trends, e.g., 1994 peaks of certain PCBs and DDT at Lake Michigan highly influenced this analysis. Another key aspect of PCB concentrations concerns the toxicity of the PCB mixture. Again comparing 4-year periods, TEQs for PCBs decreased in fish from Lakes Erie, Michigan, and Superior although only the latter was statistically significant, but TEQs increased in fish from Lakes Huron and Ontario, although changes were not statistically significant (Table 4). Approximately $52 \%$ (on average) of the calculated toxicity comes from $3,3^{\prime}, 4,4^{\prime}, 5-\mathrm{PeCB}$ (PCB no. 126), which has the greatest TEF; $\sim 15 \%$ comes from $2,3^{\prime}, 4,4^{\prime}, 5-\mathrm{PeCB}$ (PCB no. $118) ; \sim 13 \%$ comes from $\left(2,3,3^{\prime}, 4,4^{\prime}, 5-\mathrm{HxCB}\right.$ no. 156$)$, and smaller amounts come from other congeners. The TEQs are somewhat underestimated because one congener $\left(3,3^{\prime}, 4,4^{\prime}, 5,5^{\prime}-\mathrm{HxCB}\right.$, no. 169) was not measured, and three congeners $\left(3,4,4^{\prime}, 5\right.$-TCB (no. 81), 2, $3^{\prime}, 4,4^{\prime}, 5^{\prime}$-PeCB (no. 123), and $2,3^{\prime}, 4,4^{\prime}, 5,5^{\prime}-\mathrm{HxCB}$ (no. 167)) were not measured in 1991 to 1993 . However, these provide small contributions to TEQ, and the exclusion of the latter did not alter results. Also, congener no. 126 could not be determined in most samples in 1993 because of a laboratory contamination issue. Recent trends in TEQs largely follow levels of congener no. 126 (Fig. 8), in which increases (although not statistically significant) have been observed in four lakes (Table 4). This congener is present at low levels (generally $\leq 2 \mathrm{ng} / \mathrm{g}$ ), although well above MDLs (0.02 to $0.1 \mathrm{ng} / \mathrm{g}$ ). Its measurements demonstrate substantial variation, both from year to year and within years at sites (shown by the error bars on Fig. 8). Other dioxin-like PCB congeners showed downward trends, except for PCB no. 81 (which was measured along with PCB no. 87). Thus, although total PCB concentrations appear to be decreasing in most lakes, PCB toxicity, which is driven largely but not exclusively by congener no. 126, is not decreasing. In the Southern Baltic Sea, Falandysz et al. (1994) first observed that among dioxin-like PCB congeners, fish appeared to metabolize and excrete $\mathrm{PCB}$ no. 77 , thus, its concentration decreased along with total PCB levels. However, because of their greater persistence and lower biodegradability, concentrations of congeners nos. 126 and 169 did not decrease even as total PCB levels decreased. This demonstrates the importance of examining trends of individual components in mixtures such as PCBs, especially for chemicals that are more persistent, bioavailable, and/or bioaccumulative.

Aldrin and Dieldrin. Aldrin and dieldrin are the common names of two insecticides that are closely related chemically with similar toxicities. Aldrin is readily converted to dieldrin in the environment, so these two closely related compounds are considered together by regulatory bodies. As mentioned, aldrin was below MDLs for all 1991 to 1998 samples. Levels of dieldrin, which probably peaked in the late 1970s in most lakes, have very consistent behavior across the Lakes with $\mathrm{t}_{1 / 2}$ ranging from 7.7 (Ontario) to 9.4 years (Erie), and a single-compartment model, without an irreducible concentration, closely fit trends in these four lakes. (Lake Superior is excluded from this analysis because of its very poor model fit, $R^{2}=0.06$.) Allowing a two-compartment model with a small irreducible concentration provided a slight $(2 \%)$ increase in the fit for Lake Ontario, but this had the effect of decreasing $\mathrm{t}_{1 / 2}$ to 5.3 years, considerably lower than the other lakes. (In this case, $\mathrm{C}_{0}=27 \mathrm{ng} / \mathrm{g}, \mathrm{C}_{1}=218 \mathrm{ng} / \mathrm{g}$, and $\mathrm{k}_{1}=0.13 \pm 0.02$.) Comparing 1991 to 1994 with 1995 to 1998 averages, dieldrin levels decreased by $30 \%$ to $49 \%$ in four lakes, and by $86 \%$ in Lake Superior, all changes that achieve or approach statistical significance in all cases (Table 4). The decrease continues the trend reported by DeVault et al. (1996) who reported similar $t_{1 / 2}$ (6.3 years for Erie to 11.6 years for Michigan, again excluding Superior where the fit was poor). The longer data record used here obtained higher model fits $\left(R^{2}\right.$ from 0.69 to 0.88 , again excepting Lake Superior) than those reported by De Vault et al. (1996).

Chlordane. Technical-grade chlordane is a mixture of $\sim 50$ compounds with the major constituents identified as cisand trans-chlordane (38\% to $48 \%$ ), heptachlor (3\% to $13 \%$ ), cis- and trans-nonachlor (5\% to $11 \%$ ), and other chlordane isomers (17\% to $25 \%$ ) (USEPA 1998). Chlordane is primarily metabolized to oxychlordane. Heptachlor, which is also a separate pesticide, is metabolized to heptachlor epoxide. Chlordane is an unlikely source of exposure if heptachlor epoxide is found in the absence of either oxychlordane or trans-nonachlor. Based on the 1991 to 1998 data at the five lakes, trans-nonachlor is the predominant component, accounting for $43 \% \pm 4 \%$ of total chlordane. Of the other components, cis-nonachlor accounted for $22 \% \pm 4 \%$; cischlordane accounted for $17 \% \pm 5 \%$; oxychlordane accounted for $10 \% \pm 3 \%$; and trans-chlordane accounted for $3 \% \pm 3 \%$. Trans-chlordane levels often decreased below the MDL, especially in recent years. Across the lakes, these fractions were consistent except that Lake Erie walleye had the highest levels of both cis-chlordane $(25 \% \pm 4 \%)$ and trans-chlordane $(5 \% \pm 5 \%)$ but the lowest levels of oxychlordane $(5.4 \% \pm 0.8 \%)$. Also, Lake Superior trout had somewhat lower 

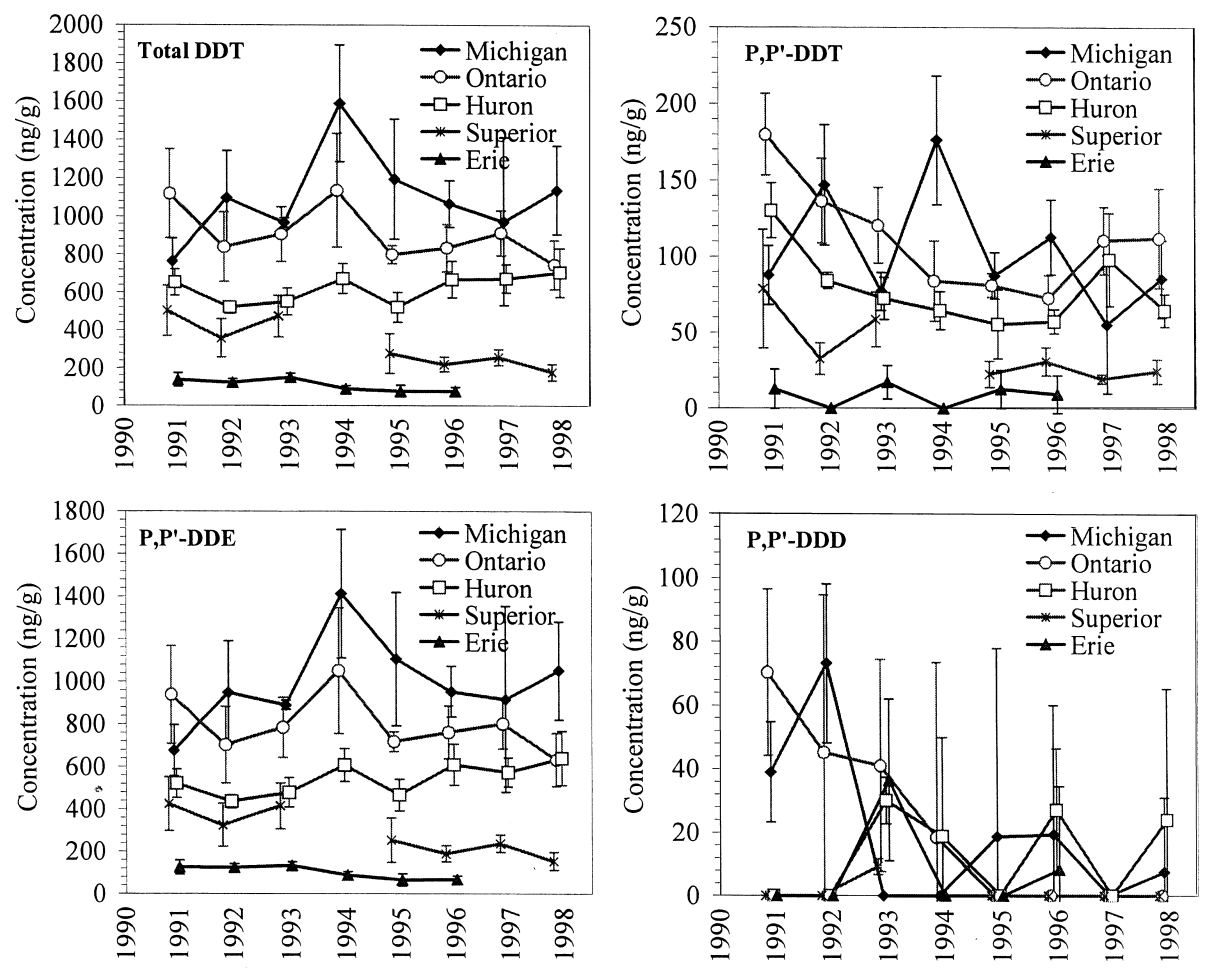

Fig. 7. Recent trends of total DDT, DDE, DDD, and $p, p^{\prime}$-DDT in fish from the five lakes. DDT = dichloro-diphenyltrichloroethane levels of cis-chlordane $(12 \% \pm 2 \%)$ than the other lakes. Overall, this behavior represents a bioaccumulated and "weathered" technical chlordane mixture.

Over the available record (1977 to 1988 in most lakes), trends of oxychlordane concentrations in fish from Lakes Michigan, Huron, and Erie decreased according to the singlecompartment first-order model with $\mathrm{t}_{1 / 2}$ from 4.1 to 9.1 years. In contrast, levels in fish from Lakes Ontario and Superior appear to have stopped decreasing, essentially reaching irreducible levels of 13 and $20 \mathrm{ng} / \mathrm{g}$, respectively. Levels have shown essentially no downward trend from 1986 to 1998 in Lake Superior and from 1992 to 1998 in Lake Ontario (note, however, that the record in the latter lake is short). Decreases tend to be steeper for the constituents of technical chlordane. In the more recent period, the cis-chlordane fraction diminished, e.g., from $20 \% \pm 1 \%$ in 1991 to $12 \% \pm 1 \%$ in 1998 for lake trout in Lakes Huron, Michigan and Ontario, whereas cisnonachlor and oxychlordane levels slightly increased. In contrast to PCBs, dieldrin, and the chlordanes, the trend models suggest that the decreases in total DDT and toxaphene may have slowed, as discussed below.

DDT. Irreducible levels, specifically, $257 \mathrm{ng} / \mathrm{g}$ in Superior, $571 \mathrm{ng} / \mathrm{g}$ in Huron, and $876 \mathrm{ng} / \mathrm{g}$ in Michigan are estimated. Although no irreducible level was estimated for Lakes Erie and Ontario, DDT trends show long $\mathrm{t}_{1 / 2}, 9.0$ and 17.7 years, respectively. These results may occur because of contaminant cycling in the environment and/or a large reservoir of this contaminant. To further examine recent (1991 to 1998) trends, DDT and its metabolites, DDE and DDD, are shown in Figure 7. The typical composition of DDT was $80 \%$ to $90 \%$ p,p'-DDE, $8 \%$ to $15 \%$ p,p'-DDT, and $2 \%$ to $5 \%$ p, $\mathrm{p}^{\prime}-\mathrm{DDD}$.
Comparing the 1991 to 1994 and 1995 to 1998 periods, total DDT levels increased by $14 \%$ in Lake Michigan $(p=0.23)$ and by $7 \%$ in Lake Huron $(p=0.24)$, changes that were not statistically significant, and total DDT decreased by $66 \%$ in Lake Superior $(p=0.01), 44 \%$ in Lake Erie $(p=0.02)$, and $19 \%$ in Lake Ontario $(p=0.05)$, changes that were statistically significant. Trends of metabolite $\mathrm{p}, \mathrm{p}^{\prime}$-DDE, which comprises the bulk of total DDT, are similar. However, generally downward trends are seen for $\mathrm{p}, \mathrm{p}^{\prime}$-DDT and $\mathrm{p}, \mathrm{p}^{\prime}$-DDD.

Toxaphene. The $\sim 670$-member toxaphene group is made up of octachloro homologues $\sim 50 \%$ of the total), and hexa- and heptachloro homologues $(\sim 40 \%)$. The first-order models indicated rapid decreases with $\mathrm{t}_{1 / 2}$ from 1.0 to 1.9 years, and irreducible levels of toxaphene in four lakes, specifically, 120, 152, 185, and $484 \mathrm{ng} / \mathrm{g}$ in Lakes Ontario, Michigan, Superior, and Huron, respectively. These models are based on relatively few data points (e.g., $n=7$ for Lake Superior), and there is considerable scatter around the trend line for all the lakes except Ontario. Therefore, the toxaphene trend models are considered to have little predictive ability. Considering the 1991 to 1998 period, large (65\% to $152 \%)$ and statistically significant decreases were seen for 4-year averages in all five lakes (Table 4). Overall, these trends are similar to those reported by Glassmeyer et al. (1997).

\section{Discussion}

The nearly 30-year record of contaminant levels in the Great Lakes shows both long- and short-term trends. For most of the 

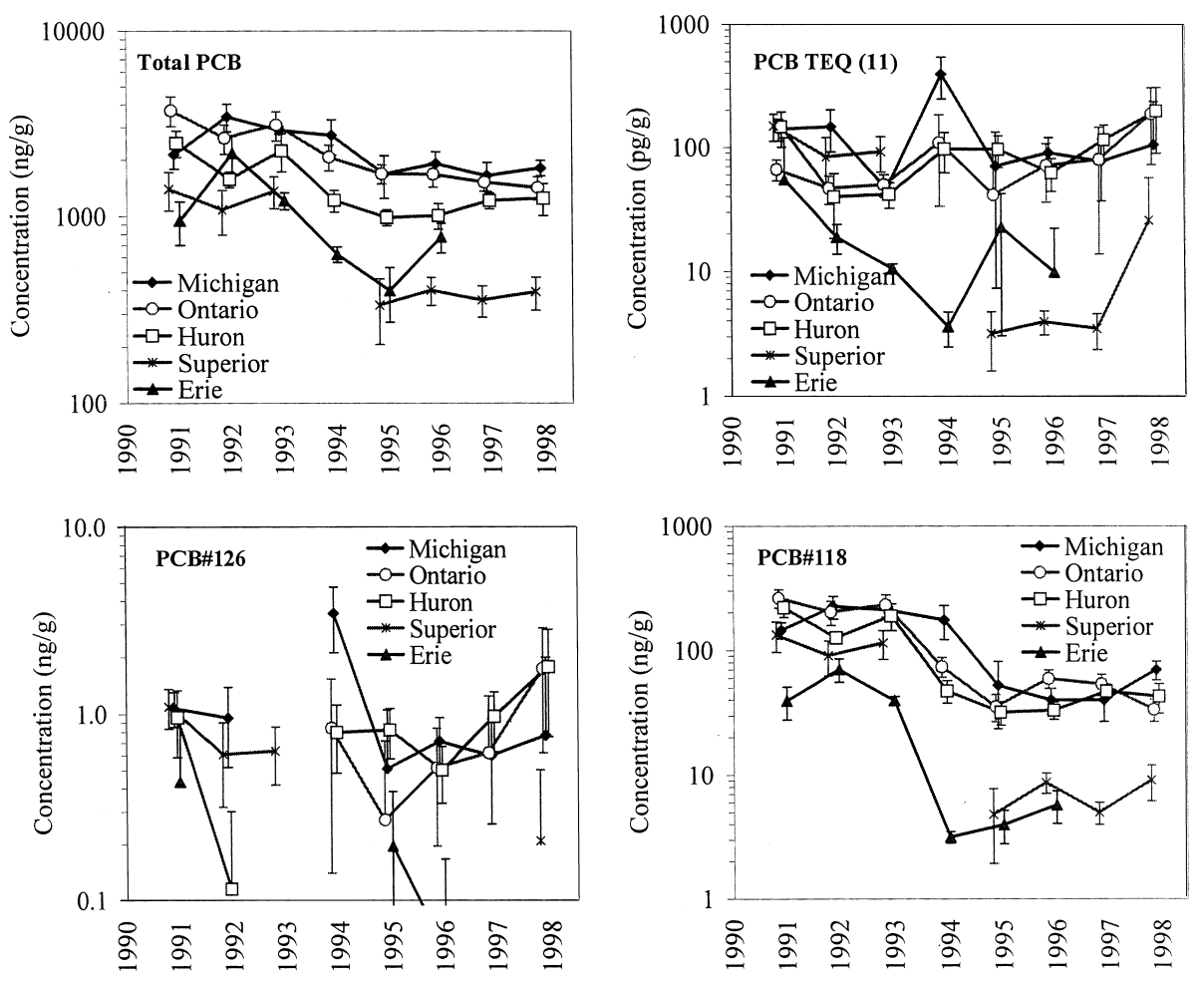

Fig. 8. Recent trends of total PCBs, PCB TEQs, PCB nos. 126 and 118 in fish from the five lakes. $\mathrm{PCB}=$ polychlorinated biphenyl; TEQ = toxic equivalency factor monitored contaminants in the basin, the long-term trend is clearly a decrease in concentration after restrictions or bans on chemical use. In many cases, however, the rate of decreases is slowing. This was quantified using multicompartment models that show in the period after curtailment of use, concentrations decreased, with $t_{1 / 2}$ generally ranging from 1 to 9 years, although in several cases, $\mathrm{t}_{1 / 2}$ is much longer, e.g., PCBs in Lake Erie $\left(\mathrm{t}_{1 / 2}=12\right.$ years $)$ and DDT in Lake Ontario $\left(\mathrm{t}_{1 / 2}=18\right.$ years). In a number of cases, contaminant concentrations are now decreasing more slowly or have reached a plateau, represented by an irreducible (constant) concentration. Slowing decreases also have been observed in fish in Canadian waters of the Great Lakes (Baumann and Whittle 1988). In some cases, large year-to-year variations cause short-term fluctuations that may obscure long-term trends, but most long-term trends seem consistent across the five Great Lakes.

Much of the short-term fluctuation in contaminant levels appears to be related to food-web dynamics and energetics. These processes play a large role in the uptake of PCBs and other persistent and lipophilic contaminants in predator fish such as lake trout and walleye. Biomagnification is the principal accumulation mechanism for species in the upper levels of the food web (Oliver and Nimi 1988; Madenjian et al. 1995). Although prey species can have comparable lipid levels and contaminant loadings, the energetics of forage and consumption can vary among species. Thus, a switch between species can dramatically alter predators' exposure to contaminants (Stow et al. 1995). Dietary changes documented in Lake Superior lake trout, for example, caused large and rapid increases in contaminant levels followed by comparable decreases. However, these diet-based fluctuations are not indicative of long-term trends, and they are not on the scale of the decreases observed in the 1970s.
Organochlorine contaminant levels in fish have not been consistently correlated with lipid content, e.g., Stow et al. (1997) found size, age, diet, and environment to be more important than lipid content in lake trout. As shown in Lake Superior trout, the lipid content of fish may change with dietary changes; thus, a correlation is expected. After correcting for the long-term trend, we found that the correlation between fish lipid content was small. For example, using Lake Michigan lake trout, the correlation between model residuals (observation-prediction) and lipid content was only 0.09 for total PCBs, -0.07 for total DDT, 0.43 for dieldrin, 0.04 for oxychlordane, and 0.00 for toxaphene. (The correlation for dieldrin decreases to 0.26 when an outlier is removed.) Thus, lipid content alone accounts for little of the variation in contaminant concentrations.

The food web of the Great Lakes was significantly altered in the 1990s by the introduction of zebra mussels. Their huge filtering capacity, encompassing particles up to $750 \mu \mathrm{m}$, includes most phytoplankton and many small invertebrates, e.g., protozoa, rotifers, and crustaceans (Fanslow et al. 1995). Filtered material is either assimilated and incorporated into biomass or deposited to the bottom sediments as feces and pseudofeces. PCBs (and other contaminants) sorbed to this settled material can constitute a biologically available reservoir, and contaminants may be transferred back to the pelagic food chain by benthic invertebrates that feed on detritus and process contaminated sediments (Landrum 1988).

\section{Conclusion}

Although concentrations of most contaminants in predator fish in the Great Lakes have continued to decrease during the 
1990s, the rapid decreases in concentrations observed through the 1970s and 1980s have slowed, and based on multicompartment first-order models, controlling processes have $t_{1 / 2}$ up to approximately 10 years. Concentrations of several contaminants, including PCB no. 126, the most toxic dioxin-like PCB congener, appear to have stabilized at or near an irreducible level. Contaminant levels in top predator fish remain a cause of concern as reflected in the fish consumption advisories, which may be expected to continue for some time. Shortterm changes in contaminant levels are explained by chemical usage and dietary changes in the fish community. Long-term trends depend on chemical transport and fate processes at the basin, regional, and even global scale, as well as on bioavailability in the food web. Lengthy data records are needed to explain trends and predict future contaminant levels and thus continued monitored is warranted in each lake.

Acknowledgments. This article is contribution no. 1330 of the USGS Great Lakes Science Center. Funding for this study was provided in part by a grant from the USEP Agency-Great Lakes National Program Office and from the Michigan Education and Research Center supported by the National Institute of Occupational Health. The authors thank Linda Begnoche and Richard Quintal at the GLSC and the many other individuals who assisted in sample collection and processing.

\section{References}

Ballschmiter K, Zell M (1980) Analysis of polychlorinated biphenyls (PCBs) by capillary gas chromatography. Fresenius Z Anal Chem 302:20-31

Battelle Memorial Institute (1999a) Great Lakes binational toxics strategy: Draft report for hexachlorobenzene (HCB): sources and regulations. United States Environmental Protection Agency, Great Lakes National Program Office, Chicago, IL

Battelle Memorial Institute (1999b) Great Lakes binational toxics strategy: Octachlorostyrene (OCS) report: A review of potential sources. United States Environmental Protection Agency, Great Lakes National Program Office, Chicago, IL

Baumann PC, Whittle DM (1988) The status of selected organics in the Laurentian Great Lakes: An overview of DDT, PCBs, dioxins, furans, and aromatic hydrocarbons. Aquat Toxicol 11:241-257

Borgmann U, Whittle DH (1983) Particle-size-conversion efficiency and contaminant concentrations in Lake Ontario biota. Can J Fish Aquat Sci 40:328-336

Borgmann U, Whittle DM (1991) Contaminant concentration trends in Lake Ontario lake trout (Salvelinus namaycush): 1977-1988. J Great Lakes Res 17:368-381

Bronte CR, Hoff MH (1999) Status of forage fish in Lake Superior, 1978-98. In: Minutes of the 1999 meeting of the Lake Superior Committee. Great Lakes Fishery Commission, Ann Arbor, MI

DeVault DS, Willford WA, Hesselberg RJ (1985) Contaminant trends in lake trout (Salvelinus namaycush) of the upper Great Lakes. United States Environmental Protection Agency 905/3 85001 and GLFL No. 639

DeVault DS, Willford WA, Hesselberg RJ, Nortrup DA, Runalberg ECS, et al. (1986) Contaminant trends in lake trout (Salvelinus namaycush) from the upper Great Lakes. Arch Environ Contam Toxicol 15:349-356

DeVault DS, Hesselberg RJ, Rodgers PW, Feist TJ (1996) Contaminant trends in Lake Trout and Walleye from the Laurentian Great Lakes. J Great Lakes Res 22:884-895
Falandysz J, Kannan K, Tanabe S, Tatsukawa R (1994) Concentrations, clearance rates and toxic potential of non-ortho coplanar PCBs in cod liver oil from the southern Baltic Sea from 1971 to 1989. Mar Pollut Bull 28:259-262

Fanslow DL, Nalepa TF, Lang GL (1995) Filtration rates of zebra mussels (Dreissena polymorpha) on natural seston from Saginaw Bay, Lake Huron. J Great Lakes Res 21:489-500

Gallinat MP, Bronte CR (1995) Food habits of lake trout in management units WI-2 and MI-2 in Lake Superior, 1985-1994. In: Minutes of the 1995 meeting of the Lake Superior Committee, appendix VIII. Great Lakes Fishery Commission, Ann Arbor, MI

Glassmeyer ST, DeVault DE, Meyers TR, Hites RA (1997) Toxaphene in Great Lakes fish: A temporal, spatial, and trophic study. Environ Sci Technol 31:84-88

Hebert CE, Norstrom RJ, Simon XY, Wesleloh DV, Macdonald CR (1994) Temporal trends and sources of PCDDs and PCDFs in the Great Lakes: Herring gull egg monitoring, 1981-1991. Environ Sci Technol 28:1268-1277

Hesselberg RJ, Gannon JE (1995) Contaminant trends in Great Lakes fish. In: LaRoe ET, Farris GS, Puckett CE, Doran PD, Mac MJ, (eds) Our living resources. Department of the Interior. National Biological Service, Washington, DC, pp 242-244

Huestis SY, Servos MR, Whittle DM, Dixon DG (1996) Temporal and age-related trends in levels of polychlorinated biphenyl congeners and organochlorine contaminants in Lake Ontario lake trout (Salvalinus namaycush). J Great Lakes Res 22:310-330

International Organisation for the Management of Chemicals (1995) POPs assessment report, December 1995. Available at: http:// www.chem.unep.ch/pops/indxhtms/asses.html. Accessed: Aug 29, 2005

James R, Hites R (2002) Atmospheric transport of toxaphene from the southern United States to the Great Lakes region. Environ Sci Technol 36:3474-3481

Kannan K, Yamashita N, Imagawa T, DeCoen W, Khim J-S, Day RM, et al. (2000a) Polychlorinated naphthalenes and polychlorinated biphenyls in fishes from Michigan waters including the Great Lakes. Environ Sci Technol 34:566-572

Kannan K, Imagawa T, Yamashita N, Miyazaki A, Giesy JP (2000b) Polychlorinated naphthalenes in sediment, fishes and fish-eating water birds from Michigan waters of the Great Lakes. Organohal Comp 47:13-16

Keith LH (1991) Environmental sampling and analysis: A practical guide. Lewis, CRC Press, Boca Raton, FL

Kiriluk RM, Whittle DM, Keir MJ, Carswell AA, Huestis SY (1997) The Great Lakes fisheries specimen bank: A Canadian perspective in environmental specimen banking. Chemosphere 34:1921-1932

Landrum PF (1988) Toxicokinetics of organic xenobiotics in the amphipod Pontoporeia hoyi: The role of physiological and environmental variables. Aquat Toxicol 12:245-271

Madenjian CP, Desorcie TJ, Stedman RM, Brown Jr, EH, Eck GW, Schmidt LJ, et al. (1999) Spatial patterns in PCB concentrations of Lake Michigan lake trout. J Great Lakes Res 25:149-159

Madenjian CP, Whittle DM, Elrod JH, O'Gorman R, Owens RW (1995) Use of a simulation model to reconstruct PCB concentrations in prey of Lake Ontario lake trout. Environ Sci Technol 29:2610-2615

Muir DCG, Jones PD, Karlsson H, Koczansky K, Stern GA, Kannan $\mathrm{K}$ et al. (2002) Toxaphene and other persistent organochlorine pesticides in three species of albatrosses from the north and south Pacific Ocean. Environ Toxicol Chem 21:413-423

Muir DCG, Whittle DM, De Vault DS, Bronte CR, Karlsson H, Backus S (2004) Bioaccumulation of toxaphene congeners in the Lake Superior food web. J Great Lakes Res 30:316-340

Oliver BG, Nimi AJ (1988) Trophodynamic analysis of polychlorinated biphenyl congeners and other chlorinated hydrocarbons in the Lake Ontario ecosystem. Environ Sci Technol 22:388-397 
Schmidt LJ (1997) Method for analysis of total PCBs and PCB congeners (full suite) and trans-nonachlor by gas chromatography/negative chemical ionization single ion mass spectrometry. Volume II of Lake Michigan mass balance study methods compendium: Organic and mercury methods. United States Environmental Protection Agency, Great Lakes National Program Office, Chicago, IL (EPA-905-R-97-012b)

Schmidt LJ, Hesselberg RJ (1992) A mass spectroscopic method for the analysis of AHH-inducing and other polychlorinated biphenyl congeners and selected pesticides in fish. Arch Environ Contam Toxicol 23:37-44

Stow CA, Carpenter SR, Amrhien JF (1994) PCB concentration trends in Lake Michigan coho (Oncorhynchus kisutch) and Chinook salmon (O. tshawytscha). Can J Fish Aquat Sci 51:1384-1390

Stow CA, Carpenter SR, Eby LA, Amrhien JF, Hesselberg (1995a) Evidence that PCBs are approaching stable concentrations in Lake Michigan fishes. Ecol Appl 5:248-260

Stow CA, Carpenter SR, Eby LA, Amrhien JF, Hesselberg RJ (1995b) Temporal patterns of PCB concentrations and predator-prey concentration ratio of Lake Michigan fishes. Ecol Appl 5:248-260

Stow CA, Jackson LJ, Amrhein JF (1997) An examination of the PCB: lipid relationship among individual fish. Can J Fish Aquat Sci 54:1031-1038

Suns KR, Hitchin GG, Toner D (1993) Spatial and temporal trends of organochlorine contaminants in spottail shiners from selected sites in the Great Lakes (1975-1990). J Great Lakes Res 19:703-714

Swackhamer DL, Schottler SP, Pearson RF (1999) Air-water exchange and mass balance of toxaphene in the Great Lakes. Environ Sci Technol 33:3864-3872
United States Environmental Protection Agency (1980) Ambient water quality for diedrin. US Environmental Protection Agency, EPA 440/5-80-019. Office of Water Quality Regulations and Standards, Washington, DC

United States Environmental Protection Agency (2005) Human health and the Great Lakes. Fish consumption. Available at: http:// www.great-lakes.net/humanhealth/fish/index.html. Accessed: Aug 29, 2005

United States Environmental Protection Agency/Integrated Risk Information System (1998) USEPA Integrated Risk Information System Substance file-Chlordane (technical) CASRN 12789-036; 02/07/1998. p. 10. Available at: http://www.epa.gov/iris/subst/ 0142.htm. Accessed: Aug 29, 2005

United States Environmental Protection Agency/United States Geological Survey (1977) Memoranda of understanding/cooperative agreement for Great Lakes Fish monitoring program (GLFMP) between EPA/CRL and USFWS/GLFL, updated July 13, 1989, between USEPA/GLNPO and USFWS/NFRC-GL, and June 10, 1996 between USEPA/GLNPO and NBS/GLSC. October 14, 1977. Ann Arbor, MI, and Chicago, IL

Whittle DM, Kiriluk RM, Carswell AA, Kier MJ, MacEachen DC (1997) Spatial and temporal variation of toxaphene in fish communities of the Great Lakes. Extended abstract. Society of Environmental Toxicology and Chemistry 18th Annual Meeting, San Francisco, CA, November 16-25

World Health Organization (1997) WHO toxic equivalency factors (TEFs) for dioxin-like compounds for humans and wildlife, June 15-18, Stockholm, Sweden 